\title{
Penerapan Model Pembelajaran Problem Posing Terhadap Hasil Belajar
}

\author{
Nuridayanti ${ }^{1}$, Muhammad Akil ${ }^{2}$, Fitrah A Darmawan ${ }^{3}$ \\ Pendidikan Vokasional Mekatronika, Universitas Negeri Makassar \\ Parang Tambung, Makassar \\ ${ }^{1}$ nuridayanti@unm.ac.id, ${ }^{2}$ muhammadakileunm.ac.id, ${ }^{3}$ fitrahdarmawan@unm.ac.id
}

\begin{abstract}
Problem posing adalah model pembelajaran yang mengharuskan peserta didik dapat menyusun soal dan menjawabnya sendiri untuk merekonstruksi pemahaman mereka, sehingga model pembelajaran ini diasumsikan dapat meningkatkan hasil belajar peserta didik. Penelitian ini dilakukan Untuk mengetahui seberapa besar hasil belajar peserta didik dengan penerapan model pembelajaran problem posing dan bagaimana pengaruh penerapan model pembelajaran problem posing terhadap hasil belajar peserta didik. Penelitian menggunakan jenis penelitian quasi eksperimen dengan menggunakan subjek penelitian berjumlah 54 peserta didik. Pengumpulan data penelitian dilakukan dengan menggunakan angket dan tes hasil belajar. Data yang ada dianalisis menggunakan uji t. Penelitian ini menunjukkan bahwa hasil belajar peserta didik dengan penerapan model pembelajaran problem posing lebih besar dibandingkan dengan model pembelajaran konvensional dan terdapat pengaruh penerapan model pembelajaran problem posing terhadap hasil belajar peserta didik.
\end{abstract}

Keywords: Hasil belajar, Problem posing.

\section{PENDAHULUAN}

A. Latar Belakang

Globalisasi merupakan sebuah proses perubahan yang menyeluruh di semua sendi-sendi kehidupan manusia. Globalisasi hadir dari perkembangan teknologi dan informasi yang begitu pesat. Salah satu tantangan internal bangsa Indonesia saat ini adalah mengupayakan SDM usia produktif yang dimiliki bangsa dapat ditransformasikan menjadi SDM yang memiliki kompetensi dan keterampilan melalui pendidikan agar tidak menjadi beban. Optimalisasi di bidang sumber daya dan kualitas secara signifikan akan meningkatkan daya saing Indonesia sebagai negara penyedia tenaga kerja terampil dan penghasil produk berkualitas bagi negara-negara di lingkup ASEAN maupun global. Sekolah Menengah Kejuruan (SMK) menjadi salah satu harapan untuk dapat menjawab tantangan internal pendidikan dan menciptakan peluang dalam memenangkan persaingan global[1].

Pelaksanaan pembelajaran di SMK mengharapkan guru dapat melakukan inovasi-inovasi pembelajaran yang dapat mendorong dan memfasilitasi peserta didik dalam melaksanakan proses belajarnya dan tidak hanya dari ranah kognitif, tetapi juga dari sikap dan kepercayaan diri dalam menghadapi berbagai tantangan serta mampu bertahan dan menghadapi akan adanya persaingan. Guru memiliki peranan yang sangat penting dalam menanamkan pengetahuan dan menumbuhkan motivasi berprestasi dan bersaing dari peserta didiknya. Guru juga harus mendesain pembelajarannya yang responsif dan berpusat pada peserta didik agar minat dan motivasi berprestasi mereka terus meningkat. Guru tidak boleh menganggap peserta didik sebagai gelas kosong untuk diisi pengetahuan. Melainkan bersama-sama dengan peserta didik membangun pengetahuan [2].

Kenyataan di lapangan menunjukkan adanya proses belajar mengajar yang umum terjadi di dalam kelas adalah menanamkan pengetahuan tanpa memperhatikan apa sebenarnya yang dibutuhkan oleh peserta didik. Dalam melaksanakan pembelajaran di kelas guru lebih cenderung mendominasi pembelajaran yang berorientasi pada teacher centered yang mengakibatkan keaktifan peserta didik dalam proses pembelajaran sangat kurang dan dapat menghambat munculnya keaktifan dan krestifitas peserta didik di kelas.

Survey awal dilakukan di SMK Negeri 2 Makassar pada mata pelajaran Teknik Listrik. Mata pelajaran teknik listrik merupakan mata pelajaran yang tergolong sulit bagi peserta didik, mata pelajaran ini mengharapkan peserta didik dapat mengembangkan pengetahuan dalam merumuskan masalah, mengajukan hipotesis dan mengujinya melalui percobaanpercobaan rangkaian serta mampu melakukan analisis untuk menafsirkan data yang diperoleh kemudian mengomunikasikannya. Sehingga kemampuan pemahaman konsep dan bernalar peserta didik sangat dibutuhkan. Pemberian metode pembelajaran konvensional yang diberikan tidak akan mampu menumbuhkan kemampuan analisis dan bernalar peserta didik, seperti terlihat pada data hasil belajar peserta didik dalam dua tahun terakhir untuk mata pelajaran teknik listrik kelas $\mathrm{X}$ Elektronika Industri dan Audio Video diperoleh rata-rata 54 dengan standar nilai ketuntasan 75 dan hanya $38 \%$ peserta didik 
yang mencapai nilai tuntas. Untuk mengatasi hal tersebut maka diperlukan adanya model pembelajaran yang berorientasi pada kemampuan pemahaman yang lebih luas yaitu dengan pendekatan model pembelajaran problem posing.

\section{LANDASAN TEORI}

\section{A. Kajian Teori}

1. Belajar dan Pembelajaran

Defenisi dan konsep belajar telah banyak dikemukakan oleh ahli, sebagai berikut; Cronbach mendefenisikan "Learning is shown by a change in behavior as a result of experience". Harold Spears mengungkapkan bahwa belajar adalah mengamati, membaca, meniru, mencoba sesuatu sendiri, mendengarkan dan mengikuti arahan. Sedangkan Geoch, mengatakan bahwa belajar adalah perubahan hasil kinerja sebagai akibat dari adanya pelatihan. Lebih lanjut dikatakan bahwa belajar itu senantiasa merupakan perubahan tingkah laku atau penampilan, dengan serangkaian kegiatan misalnya dengan membaca, mengamati, mendengarkan, meniru dan lain sebagainya. Perubahan tingkah laku atau penampilan tersebut merupakan hasil dari belajar yang dilakukan. [3].

Belajar adalah perubahan yang umumnya terjadi sebagai akibat dari adanya latihan atau pengalaman. Sedangkan James L. Mursell memberikan pengertian bahwa belajar merupakan upaya yang dilakukan seseorang dengan mengalami sendiri, menjelajahi, menelusuri, dan memperoleh sendiri. Sehingga belajar menjadi suatu aktivitas mental (psikis) yang berlangsung dalam interaksi dengan lingkungannya yang menghasilkan perubahan yang bersifat relatif konstan [4][5][6].

Belajar sebagai suatu proses yang memiliki tiga ciri, yaitu: (a) proses tersebut membawa perubahan (baik aktual maupun potensial), (b) perubahan itu pada dasarnya didapatkannya kecakapan baru, dan (c) perubahan itu terjadi dengan sengaja. Belajar menjadi aktifitas yang dilakukan individu untuk memperoleh penghidupan yang baik[7].

Perspektif tentang berbagai pengertian belajar diatas, dapat di tarik kesimpulan bahwa belajar adalah suatu proses dalam diri seseorang yang menghasilkan perubahan tingkah laku yang sifatnya permanen atau tetap. Sehingga seseorang dikatakan belajar jika telah mengalami perubahan pada tingkah lakunya sebagai hasil dari pengalamannya sendiri. Perubahan tingkah laku ini dapat mengarah pada hal yang lebih baik maupun hal yang lebih buruk tergantung dari interaksi dengan lingkungannya.

Model pembelajaran menurut Joyce \& Weil adalah suatu rencana atau pola yang dapat digunakan untuk membentuk kurikulum (rencana jangka panjang), merancang bahan-bahan pembelajaran dan membimbing pembelajaran di kelas atau yang lain. Model pembelajaran dapat dijadikan pola pilihan. Model ini dapat dipilih yang sesuai dan efesien untuk mencapai tujuan pendidikan[8].

Sebelum menentukan model pembelajaran yang akan digunakan dalam kegiatan pembelajaran, beberapa hal yang harus dipertimbangkan, yaitu: (a) pertimbangan terhadap tujuan yang hendak dicapai. Pertimbangan ini meliputi: apakah tujuan pembelajaran yang ingin dicapai berkenaan dengan kompetensi akademik, kepribadian, sosial dan kompetensi vokasional (b) pertimbangan yang berhubungan dengan bahan atau materi pembelajaran, (c) pertimbangan dari sudut peserta didik atau siswa. Pertimbangan ini meliputi: apakah model pembelajaran sesuai dengan tingkat kematangan, minat, bakat, kondisi dan gaya belajar peserta didik, (d) pertimbangan lainnya yang bersifat non teknis, meliputi: untuk mencapai tujuan hanya cukup dengan satu model pembelajaran dan apakah model pembelajaran itu memiliki nilai efektivitas atau efesiensi[8].

Pemilihan model pembelajaran sebaiknya didasarkan atas pertimbangan mengenai kebutuhan peserta didik. Pemilihan yang tepat akan memungkinkan pelaksanaan pendidikan akan efesien dengan mempertimbangkan sifat-sifat peserta didik sehingga kualitas pembelajaran yang terjadi dalam kelas dapat meningkat.

Penelitian Silver dan Cai menunjukkan bahwa kemampuan dalam perumusan masalah berkorelasi positif dengan kemampuan memecahkan masalah. Keikutsertaan dan partisipasi aktif dari peserta didik tentunya menjadi hal yang utama dalam kegiatan belajar mengajar[9].

Lyn D. English pada tahun 1998 mulai menerapkan dan mengembangkanmodel pembelajaran problem posing dengan menerapkannya pada mata pelajaran matematika dan sains. Menurut Sutiarso problem posing merupakan istilah dalam bahasa Inggris, sebagai padanan katanya digunakan istilah merumuskan masalah (soal) atau membuat masalah (soal). Pada dasarnya model pembelajaran problem posing adalah suatu model pembelajaran yang mewajibkan peserta didik untuk mengajukan soal melalui pelajaran membuat soal[10][11].

Sejalan dengan itu, Sriwenda menyatakan bahwa problem posing merupakan pengajuan soal yang dibuat berdasarkan situasi yang diberikan guru kepada peserta didik. Sementara itu, Hafsanuddin menyebutkan bahwa problem posing adalah salah satu alternatif pendekatan pembelajaran yang dapat meningkatkan keterampilan berfikir dan hasil belajar peserta didik[12].

Berdasarkan uraian di atas dapat disimpulkan bahwa problem posing merupakan model pembelajaran yang mengharuskan peserta didik menyusun pertanyaan sendiri atau memecahkan suatu soal menjadi pertanyaan-pertanyaan yang lebih sederhana yang mengacu pada penyelesaian soal tersebut berdasarkan situasi awal yang diberikan, soalsoal yang dipecah merupakan kunci untuk mendapatkan kunci untuk menyelesaikan soal utama yang telah diberikan. Jadi, pada prinsipnya model pembelajaran problem posing adalah suatu model pembelajaran yang mewajibkan para peserta didik untuk mengajukan soal dan menyelesaikannya melalui belajar membuat soal. Melalui pemilihan model pembelajaran problem posing diharapkan peserta didik terbiasa dan terlatih untuk mengajukan pertanyaan, serta sumber informasi yang diterima peserta didik tidak hanya dari guru tetapi juga dapat meningkatkan peran serta dan keaktifan peserta didik dalam mencari referensi lain, mempelajari dan menelaah ilmu untuk membantu menyelesaikan permasalahan mereka[13].

Mishra dan Iyer membagi pendekatan problem posing ke dalam tiga tahap, seperti pada gambar 1[14]: 


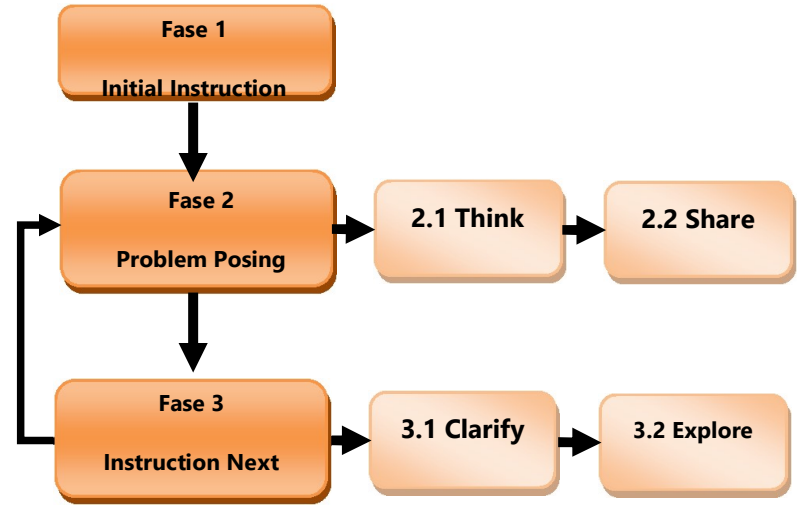

Gambar 1. Tahap-tahap pelaksanaan problem posing

Fase 1 instruksi awal, pada tahap ini ditandai dengan pemberian instruksi awal (seed) pada peserta didik oleh guru. Pengetahuan awal ini oleh Mishra dan Iyer disebut dengan "Seed Knowledge" atau benih pengetahuan yang secara eksplisit memiliki petunjuk atau komponen yang dapat mendorong pertanyaan eksplorasi pada peserta didik. Seperti pernyataan Mayer \& Moreno yang dikutip oleh Mishra \& Iyer "The initial instruction was light (less incontent), and short (of short time), to ensure that students assimilate most of its contents". Peserta didik bebas untuk membuat catatan atau menulis pertanyaan secara bersama-sama untuk mempermantap pemahamannya[14].

Fase 2 problem posing, pada tahap ini terdiri atas dua sub fase yaitu peserta didik diminta untuk mengajukan soal atau pertanyaan seputar pengetahuan awal "seed" yang telah diberikan pada tahap sebelumnya. Setelah selesai membuat pertanyaan berdasarkan seed yang diberikan, selanjutnya peserta didik membagi pertanyaan mereka antar satu teman dengan teman yang lain atau satu kelompok dengan kelompok yang lain. Pertanyaan yang telah dibuat dan dibagikan kemudian dicari solusi atau pemecahan secara individu ataupun berkelompok.

Fase 3 instruksi lanjutan, pada tahap ini terdiri atas dua fase juga yaitu klarifikasi dan ekplorasi. Klarifikasi dilakukan untuk menentukan jenis respon yang diberikan peserta didik. Selanjutnya ekplorasi digunakan untuk mengkonstruksi pengetahuan baru oleh peserta didik.

Sedangkan Astra, menjelaskan penerapan model pembelajaran problem posing tipe pre-solution posing adalah sebagai berikut[10]: TABEL I

TAHAP-TAHAP PELAKSANAAN PROBLEM POSING

\begin{tabular}{|c|l|}
\hline Tahap Problem Posing & \multicolumn{1}{|c|}{ Penjelasan } \\
\hline a. Menguraikan Isi & $\begin{array}{l}\text { Guru menjelaskan materi } \\
\text { kepada peserta didik, jika perlu } \\
\text { untuk memperjelas konsep } \\
\text { menggunakan guru } \\
\text { memberikan peserta didik kode. }\end{array}$ \\
\hline b. Menggambarkan \\
Masalah & $\begin{array}{l}\text { Guru memberikan contoh- } \\
\text { contoh soal dan memberikan } \\
\text { stimulus berupa gambar, kisah } \\
\text { atau cerita, diagram, } \\
\text { pemaparan dan lain-lain. }\end{array}$ \\
\hline
\end{tabular}

\begin{tabular}{|c|c|c|}
\hline C. & $\begin{array}{l}\text { Membuat } \\
\text { Masalah }\end{array}$ & $\begin{array}{l}\text { Guru memberi latihan dengan } \\
\text { model problem posing tipe pre- } \\
\text { solution posing dengan } \\
\text { mengaitkan masalah yang } \\
\text { berhubungan dengan } \\
\text { kehidupan sehari-hari. }\end{array}$ \\
\hline d. & $\begin{array}{c}\text { Mendiskusikan } \\
\text { Masalah }\end{array}$ & $\begin{array}{l}\text { Pada tahap ini seorang guru } \\
\text { menjadi fasilitator untuk } \\
\text { memandu peserta didiknya } \\
\text { berdiskusi untuk memecahkan } \\
\text { masalah. Fasilitator atau guru } \\
\text { hanya memantau dan } \\
\text { mengarahkan jalannya kegiatan } \\
\text { belajar mengajar, tidak boleh } \\
\text { ikut terlibat dalam pemecahan } \\
\text { masalah. }\end{array}$ \\
\hline & $\begin{array}{c}\text { Mendiskusikan } \\
\text { Alternatif } \\
\text { Pemecahan } \\
\text { Masalah }\end{array}$ & $\begin{array}{l}\text { Guru membahas tugas yang } \\
\text { diberikan dengan model } \\
\text { problem posing dan melatih } \\
\text { peserta didik untuk mencari } \\
\text { kemungkinan pertanyaan lain } \\
\text { yag didapat dari stimulus. }\end{array}$ \\
\hline
\end{tabular}

Berdasarkan beberapa langkah-langkah pembelajaran dengan pendekatan problem posing dapat disimpulkan bahwa pelaksanaan pembelajaran problem posing dimulai dengan pemberian pengetahuan awal kepada peserta didik. Pada tahap ini peserta didik diharapkan dapat menghubungkan pengetahuan yang baru mereka peroleh dengan pengetahuan yang sudah mereka miliki. Pemberian contoh-contoh soal dan cara pemecahannya pada tahap ini sangat disarankan untuk menambah pemahaman peserta didik.

Tahap berikutnya adalah pembuatan soal oleh peserta didik secara berkelompok berdasarkan informasi dan pengetahuan awal yang telah diberikan oleh guru. Pembuatan soal dilakukan dengan memanfaatkan berbagai sumber yang ada. Pada tahap ini peserta didik mencari solusi dan pemecahan dari soal yang telah dibuat dan mempresentasikannya di depan kelas. Pengecekan pengetahuan dan pemahaman peserta didik dilakukan pada tahap ini sebelum melanjutkan pada tahap berikutnya. Peran aktif guru dalam membimbing peserta didik sangat dibutuhkan pada tahap ini.

Tahap selanjutnya adalah pemberian pelatihan lanjutan yaitu dengan meminta peserta didik untuk kembali membuat soal (merumuskan masalah). Soal yang telah dibuat oleh masing-masing kelompok kemudian dibagikan kepada kelompok yang lain dan didiskusikan cara pemecahannya dalam kelompok. Setelah menemukan pemecahannya maka setiap kelompok kembali akan mempresentasikan hasil temuan mereka dan meminta tanggapan dari kelompok lain. Tahap terakhirnya yaitu penarikan kesimpulan dan pemantapan terhadap konsep yang telah diberikan. Guru memberikan penjelasan dan penegasan konsep terhadap materi yang dibahas kemudian menuliskan kesimpulan. 
Jurnal MediaTIK : Jurnal Media Pendidikan Teknik Informatika dan Komputer

\section{METODE PENELITIAN}

Pengaruh penerapan model pembelajaran problem posing terhadap hasil belajar peserta didik kelas X Program Studi Keahlian Teknik Elektronika di SMK Negeri 2 Makassar di teliti dengan menggunakan penelitian quasi experiment (eksperimen semu). Jenis penelitian ini menggunakan kelompok eksperimen dan kelompok kontrol yang tidak di bentuk dari pengambilan subjek secara acak, sehingga variabel-variabel luar yang mempengaruhi pelaksanaan eksperimen tidak dapat dikontrol sepenuhnya.

Pelaksanaan penelitian ini menggunakan Nonequivalent Control Group Design sebagai desain penelitian dengan kelompok eksperimen dan kelompok kontrol. Pemilihan kelompok eksperimen maupun kelompok kontrol tidak dilakukan secara random. Pada kelompok eksperimen menggunakan metode pembelajaran dengan pendekatan problem posing sedang kelompok kontrol tidak menggunakan model problem posing tetapi menggunakan pendekatan pembelajaran konvensional[15].

Data pretest dianalisis menggunakan uji normalitas, homogenitas dan uji t untuk mengetahui ada tidaknya perbedaan skor rata-rata hasil pretest antara kelas eksperimen dengan kelas kontrol. Analisis ini juga dimaksudkan untuk mengetahui kemampuan awal peserta didik pada kedua kelas tersebut adalah setara dan layak untuk diperbandingkan. Pengujian normalitas menggunakan uji Kolmogorov-Smirnov dengan ketentuan jika Asymp. Sig $>0,05$ maka data berdistribusi normal. Sedangkan kriteria penentuan homogenitas yaitu jika nilai signifikan $>0,05$ maka data terbukti homogen. Uji t yang digunakan mengacu pada nilai signifikansi 0,05 . Jika nilai sigifikansi yang diperoleh kurang dari 0,05 maka kedua kelas tersebut tidak setara. Jika nilai signifikansi lebih besar dari 0,05 maka kedua kelas setara.

Untuk uji hipotesis, peneliti menggunakan uji t. Hipotesis yang diajukan dalam penelitian ini adalah:

1. Hipotesis 1

H0 : $\left(\mu \_1 \geq \mu \_2\right)$ tidak ada pengaruh penerapan model pembelajaran problem posing terhadap motivasi belajar peserta didik.

H1 : $\left(\mu \_1<\mu \_2\right)$ ada pengaruh penerapan model pembelajaran problem posing terhadap motivasi belajar peserta didik.

2. Hipotesis 2

H0 : $\left(\mu \_1 \geq \mu \_2\right)$ tidak ada pengaruh penerapan model pembelajaran problem posing terhadap hasil belajar peserta didik.

Kriteria pengujiannya yaitu jika $\mathrm{t}$ hitung lebih kecil dari $\mathrm{t}$ tabel maka $\mathrm{H} 0$ diterima dan jika thitung lebih besar dari t tabel maka $\mathrm{H} 0$ ditolak. Sedangkan untuk kriteria pengujian signifikansi yaitu apabila signifikansi lebih besar dari 0,05 maka H0 diterima dan apabila signifikansi lebih kecil atau sama dengan 0,05 maka H0 ditolak.

\section{HASIL DAN PEMBAHASAN}

\section{A. Hasil Penelitian}

Perolehan data hasil belajar dilakukan dengan memberikan tes sebanyak dua kali kepada peserta didik. Tes kemampuan awal (pretest) merupakan tes yang diberikan kepada peserta didik pada kelas eksperimen maupun kelas kontrol sebelum diberikan perlakuan pendekatan pembelajaran problem posing pada kelas eksperimen dan pembelajaran konvensional pada kelas kontrol. Tes kemampuan akhir (posttest) merupakan tes yang diberikan kepada peserta didik baik kelas eksperimen maupun kelas kontrol setelah diberi perlakuan. Data hasil belajar peserta didik pada kelas eksperimen maupun kelas kontrol dapat dilihat Tabel 4.

TABEL II

STATISTIK DESKRIPTIF HASIL BELAJAR PESERTA DIDIK MATA PELAJARAN TEKNIK LISTRIK PADA KELAS EKSPERIMEN DAN KELAS KONTROL

\begin{tabular}{|c|c|c|c|c|}
\hline \multirow{2}{*}{} & \multicolumn{4}{|c|}{ Nilai } \\
\cline { 2 - 5 } & \multicolumn{2}{|c|}{ Kelas Eksperimen } & \multicolumn{2}{c|}{ Kelas Kontrol } \\
\cline { 2 - 5 } & Pretest & Posttest & Pretest & Posttest \\
\hline Subjek & 28 & 28 & 26 & 26 \\
\hline Rata-rata & 16.57 & 79.68 & 17.69 & 74.96 \\
\hline Median & 17 & 80 & 18.5 & 77 \\
\hline $\begin{array}{c}\text { Standar } \\
\text { Deviasi }\end{array}$ & 6.968 & 7.621 & 8.118 & 8.798 \\
\hline Varians & 48.55 & 58.078 & 65.902 & 77.398 \\
\hline Rentang & 20 & 27 & 27 & 30 \\
\hline $\begin{array}{c}\text { Nilai } \\
\text { Terendah }\end{array}$ & 7 & 63 & 3 & 60 \\
\hline $\begin{array}{c}\text { Nilai } \\
\text { Tertinggi }\end{array}$ & 27 & 90 & 30 & 90 \\
\hline Jumlah Nilai & 464 & 2231 & 460 & 1949 \\
\hline
\end{tabular}

Berdasarkan Tabel 2 dapat dilihat terdapat perbedaan hasil belajar peserta didik antara kelas eksperimen yang diajar menggunakan model pembelajaran problem posing dengan kelas kontrol yang diajar tanpa menggunakan model pembelajaran problem posing. Hal ini terlihat dari nilai rata-rata hasil belajar peserta didik pada kelas eksperimen dan kelas kontrol. Nilai ratarata pretest pada kelas eksperimen 16.57 sedangkan pada kelas kontrol 17.69. Setelah pemberian perlakukan yang berbeda pada kedua kelas tersebut nilai rata-rata hasil belajar posttest pada kelas eksperimen sebesar 79.69 sedangkan pada kelas kontrol sebesar 74.96. Data tersebut menunjukkan rata-rata hasil belajar pada kelas eksperimen lebih tinggi dibandingkan dengan kelas kontrol.

TABEL III

DISTRIBUSI FREKUENSI DAN KATEGORISASI HASIL

BELAJAR PESERTA DIDIK PADA MATA PELAJARAN

TEKNIK LISTRIK

\begin{tabular}{|c|c|c|c|c|c|c|c|c|}
\hline \multirow{2}{*}{ Kategori } & \multicolumn{4}{|c|}{ Kelas Eksperimen } & \multicolumn{4}{c|}{ Kelas Kontrol } \\
\cline { 2 - 9 } & \multicolumn{2}{|c|}{ Pretest } & \multicolumn{2}{c|}{ Posttest } & \multicolumn{2}{c|}{ Pretest } & \multicolumn{2}{c|}{ Posttest } \\
\cline { 2 - 9 } & Frek & $\%$ & Frek & \% & Frek & $\%$ & Frek & $\%$ \\
\hline $\begin{array}{c}\text { Sangat } \\
\text { Baik }\end{array}$ & 0 & 0 & 8 & 29 & 0 & 0 & 4 & 15 \\
\hline Baik & 0 & 0 & 16 & 57 & 0 & 0 & 13 & 50 \\
\hline
\end{tabular}


Jurnal MediaTIK : Jurnal Media Pendidikan Teknik Informatika dan Komputer

\begin{tabular}{|c|c|c|c|c|c|c|c|c|}
\hline Cukup & 0 & 0 & 4 & 14 & 0 & 0 & 9 & 35 \\
\hline Kurang & 28 & 100 & 0 & 0 & 26 & 100 & 0 & 0 \\
\hline Jumlah & 28 & 100 & 28 & 100 & 26 & 100 & 26 & 100 \\
\hline
\end{tabular}

Tabel 3 menunjukkan peningkatan hasil belajar peserta didik pada kelas eksperimen maupun kelas kontrol yang dilihat dari hasil belajar pada pretest dan posttest. Distribusi nilai pretest, baik pada kelas eksperimen maupun kelas kontrol berada pada kategori kurang. Hasil ini menunjukkan bahwa pada kelas eksperimen maupun kelas kontrol memiliki kemampuan awal yang sama pada mata pelajaran Teknik Listrik materi sel elektrokimia dan transformator.

Hasil belajar pada kelas eksperimen setelah dilakukan penerapan model pembelajaran problem posing menunjukkan hasil yang cukup signifikan dengan hasil belajar pada kelas kontrol. Distribusi nilai menunjukkan sebesar $29 \%$ peserta didik memperoleh hasil belajar dengan kategori sangat baik pada kelas eksperimen sementara pada kelas kontrol sebesar 15\%. Untuk hasil belajar kategori baik, pada kelas eksperimen diperoleh 57\% dan kelas kontrol sebesar 50\%. Selebihnya hasil belajar dengan kategori cukup sebesar $14 \%$ untuk kelas eksperimen dan 35\% pada kelas kontrol.

Penentuan ketuntasan peserta didik ditetapkan berdasarkan Standar Ketuntasan minimal (KKM) yang digunakan di sekolah. Nilai KKM untuk mata pelajaran teknik listrik yang ditetapkan adalah 75. Analisis ketuntasan peserta didik pada kelas eksperimen dan kelas kontrol dapat dilihat pada tabel 4.

TABEL IV

ANALISIS KETUNTASAN HASIL BELAJAR PESERTA DIDIK

MATA PELAJARAN TEKNIK LISTRIK UNTUK KELAS EKSPERIMEN DAN KELAS KONTROL

\begin{tabular}{|c|c|c|c|c|c|}
\hline \multirow{2}{*}{ Nilai } & \multirow{2}{*}{ Kategori } & \multicolumn{2}{|c|}{$\begin{array}{c}\text { Kelas } \\
\text { Eksperimen }\end{array}$} & \multicolumn{2}{c|}{ Kelas Kontrol } \\
\cline { 3 - 6 } & & Frek & $\%$ & Frek & $\%$ \\
\hline $75-100$ & Tuntas & 22 & 79 & 15 & 58 \\
\hline $0-74$ & Tidak Tuntas & 6 & 21 & 11 & 42 \\
\hline \multicolumn{2}{|c|}{ Jumlah } & 28 & 100 & 26 & 100 \\
\hline
\end{tabular}

Hasil analisis ketuntasan peserta didik menunjukkan pada kelas eksperimen sebesar $79 \%$ peserta didik masuk dalam kategori tuntas dan $21 \%$ hasil belajar peserta didik masuk dalam kategori tidak tuntas. Sedangkan pada kelas kontrol 58\% hasil belajar peserta didik untuk kategori tuntas dan sebesar $42 \%$ dalam kategori tidak tuntas. Data ini menunjukkan hasil belajar peserta didik pada kelas eksperimen lebih tinggi daripada hasil belajar peserta didik pada kelas kontrol.

Uji Normalitas data dihitung menggunakan uji Kolmogorov-Smirnov. Berdasarkan data yang diperoleh dari tabel uji Kolmogorov-Smirnov dapat disimpulkan bahwa data berdistribusi normal karena memiliki signifikansi $>0,05$. Hal ini menunjukkan bahwa data yang diperoleh dari angket motivasi dan tes hasil belajar pada kelas eksperimen dan kelas kontrol berasal dari populasi yang berdistribusi normal. Karena data yang diperoleh berdistribusi normal, maka uji statistik parametrik dapat digunakan pada penelitian ini.

Uji homogenitas data dimaksudkan untuk menguji apakah data yang diperoleh dari hasil angket motivasi dan hasil pretest serta posttest dari kelas eksperimen dan kelas control memiliki data homogen atau tidak. Suatu distribusi data dikatakan homogen jika taraf signifikansinya lebih besar dari 0,05 . Sedangkan taraf signifikansi kurang dari 0,05 maka distribusi data dikatakan tidak homogen. Uji homogenitas dilakukan pada setiap data yang diperoleh, yaitu data motivasi belajar, data kemampuan awal dan data hasil belajar.

Untuk uji homogenitas pada data pretest diperoleh nilai signifikansi $\alpha=0,571$ sedangkan pada uji homogenitas posttest, diperoleh nilai signifikansi 0,286 . Nilai signifikansi yang diperoleh tersebut $>\alpha=0,05$ sehingga disimpulkan data hasil pretsest dan posttest pada kelas eksperimen dan kelas kontrol memiliki varians yang sama (homogen).

B. Uji Hipotesis

Uji hipotesis yang digunakan dalam penelitian ini adalah uji statistik parametrik, yaitu menggunakan One Sample t- test dan Independent Sample t-test. Uji ini digunakan untuk mengambil keputusan apakah hipotesis yang diajukan diterima atau ditolak.

Hasil analisis uji $\mathrm{t}$ dapat dilihat pada tabel 5. Tabel tersebut menunjukkan hasil Sig. (2-tailed) adalah 0,588 yang artinya lebih besar dari 0,05 dan hasil uji t menunjukkan nilai minus (-) yang berarti jauh dari nilai $t$ tabel. Oleh karena itu, maka H0 diterima. Dengan kata lain kemampuan awal peserta didik pada kelas eksperimen dan kelas kontrol pada mata pelajaran Teknik Listrik adalah sama. Sehingga kedua kelas layak untuk dibandingkan.

TABEL V

HASIL UJI HIPOTESIS KEMAMPUAN AWAL PESERTA DIDIK PADA KELAS EKSPERIMEN DAN KELAS KONTR

\begin{tabular}{|c|l|c|l|l|c|c|}
\hline $\boldsymbol{\alpha}$ & \multicolumn{1}{|c|}{ Kelas } & $\mathbf{N}$ & Rata-rata & t hitung & ttabel & Sig. \\
\hline \multirow{2}{*}{0,05} & Eksperimen & 28 & 16,57 & \multirow{2}{*}{$-0,546$} & \multirow{2}{*}{2,006} & 0,588 \\
\cline { 2 - 5 } & Kontrol & 26 & 17,69 & & & \\
\hline
\end{tabular}

Hasil analisis uji t atau uji beda dari hasil belajar peserta didik setelah mendapatkan perlakuan yang berbeda dalam penyampaian materi (posttest) dapat dilihat pada tabel 6. Tabel tersebut menunjukkan nilai $\mathrm{t}$ hitung sebesar 2,110 dengan signifikansi 0,040 . Nilai signifikansi yang menunjukkan 0,040 lebih kecil dari 0,05 maka H0 yang menyatakan tidak ada perbedaan hasil belajar Teknik Listrik peserta didik yang diajar dengan menerapkan model pembelajaran problem posing dengan peserta didik yang diajar tanpa menggunakan model pembelajaran problem posing ditolak, sehingga data menunjukkan bahwa penerapan model pembelajaran problem posing pada kelas kontrol dan kelas eksperimen terdapat perbedaan. Hal tersebut juga dapat dilihat dari adanya perbedaan nilai rata-rata yang diperoleh peserta didik pada kelas eksperimen sebesar 79,68 lebih besar dari ratarata yang diperoleh peserta didik pada kelas kontrol sebesar 74,96. Penerapan model pembelajaran problem posing mampu meningkatkan rata-rata hasil belajar peserta didik pada kelas 
eksperimen sebesar 4,7 point dibandingkan dengan nilai rata-rata hasil belajar peserta didik pada kelas kontrol.

TABEL VI

HASIL UJI HIPOTESIS HASIL BELAJAR PESERTA DIDIK PADA KELAS EKSPERIMEN DAN KELAS KONTROL

\begin{tabular}{|c|l|c|l|l|c|c|}
\hline $\boldsymbol{\alpha}$ & \multicolumn{1}{|c|}{ Kelas } & $\mathbf{N}$ & Rata-rata & thitung & ttabel & Sig. \\
\hline \multirow{2}{*}{0,05} & Eksperimen & 28 & 79,68 & \multirow{2}{*}{2,110} & 2,006 & 0,040 \\
\cline { 2 - 7 } & Kontrol & 26 & 74,96 & & & \\
\hline
\end{tabular}

Data di atas menunjukkan nilai thitung bernilai positif dan lebih besar dari t tabel sehingga $\mathrm{H} 0$ di tolak dan $\mathrm{H} 1$ diterima, maka dapat disimpulkan bahwa ada penerapan model pembelajaran problem posing terhadap hasil belajar peserta didik. Hasil analisis tersebut menunjukkan bahwa ada pengaruh yang signifikan dari penerapan model pembelajaran problem posing terhadap peningkatan hasil belajar peserta didik pada mata pelajaan Teknik Listrik di SMK Negeri 2 Makassar.

Penerapan model pembelajaran problem posing dilakukan untuk merangsang keterlibatan peserta didik dalam kelas sehingga mampu menggali konsep pengetahuan yang dibutuhkan dalam memecahkan masalah. Pengetahuan hanya akan muncul melalui penemuan-penemuan kembali, penyelidikan dari rasa penasaran, tidak sabar dan berkelanjutan yang dilakukan oleh manusia satu dengan manusia yang lainnya dan problem posing adalah model pembelajaran yang akan memanfaatkan kekuatan luar biasa dari banyak pikiran yang bekerja bersama-sama. Guru tidak lagi sebagai guru dan pemberi kebijakan, melainkan guru menjadi pendengar, fasilitator, dan sebagai pembelajar. Karena seorang guru akan sangat berkualitas dan efektif jika ia tahu kapan harus mendengarkan peserta didiknya.

Dalam pembelajaran problem posing peserta didik diharuskan mampu merumuskan atau membuat soal sendiri kemudian menjawabnya berdasarkan materi yang telah diberikan. Kegiatan ini memungkinkan peserta didik memunculkan soal-soal yang lebih sederhana untuk menyelesaikan soal yang lebih kompleks. Model pembelajaran ini dimulai dengan memberikan materi dan informasi awal kepada peserta didik. Berdasarkan materi tersebut peserta didik diminta membuat dan merumuskan soal. Dalam membuat soal peserta didik diberi kesempatan membaca dan mengumpulkan informasi dari berbagai sumber. Tahapan terakhir dalam model pembelajaran ini adalah peserta didik menguji alternatif jawaban untuk merumuskan solusi umum dari soal yang diberikan.

Perbedaan distribusi pengaktegorian dan rata-rata nilai hasil belajar posttest peserta didik untuk kelas eksperimen yang diajar dengan penerapan model pembelajaran problem posing berada pada kategori cukup, baik dan sangat baik. Data tersebut menunjukkan peningkatan hasil belajar peserta didik yang cukup signifikan pada kelas eksperimen, sehingga dapat dikatakan bahwa pendekatan problem posing berpengaruh baik terhadap hasil belajar peserta didik pada mata pelajaran Teknik Listrik. Hasil tersebut menunjukkan bahwa rumusan masalah yang kedua dalam penelitian ini telah terjawab, yaitu hasil belajar peserta didik dengan penerapan model pembelajaran problem posing lebih besar dibandingkan dengan model pembelajaran konvensional.

Hasil penelitian ini sejalan dengan hasil penelitian yang dilakukan oleh daponte yang menyatakan bahwa penerapan model pembelajaran problem posing mampu membuat peserta didik terlibat dan aktif dalam mengajukan pertanyaan mengenai data yang diberikan, mencari dan merumuskan alternatif jawaban dari serangkaian contoh yang diberikan, menghasilkan sub permasalahan yang lebih mudah dipecahkan untuk menyelesaikan masalah yang lebih besar, menguji alternatif jawaban dan merumuskannya kembali, dan melakukan generalisasi untuk mendapatkan solusi umum dari permasalahan yang diberikan[17].

Selain itu, penelitian yang dilakukan oleh Astra juga menyatakan bahwa model pembelajaran problem posing berpengaruh dalam meningkatkan aktifitas peserta didik dalam kegiatan belajar mengajar dikelas. Penelitian yang sama dilakukan oleh Wulandari dengan hasil penelitian yang menunjukkan bahwa penerapan model pembelajaran problem posing dapat meningkatkan motivasi belajar peserta didik yang ditandai dengan meningkatnya aktifitas dan hasil belajar peserta didik dalam pembelajaran[10][16].

Adanya penerapan perlakukan yang berbeda dalam menyampaikan dan menyajikan materi kepada peserta didik ini, yaitu pada kelas eksperimen peserta didik membuat dan menjawab soal sendiri bukan sebagai tes melainkan sebagai model pembelajaran dalam mengaktifkan peserta didik dalam pembelajaran. Tuntutan membuat soal dan menjawabnya sendiri menjadikan peserta didik aktif dalam mencari berbagai sumber dan referensi untuk memenuhi tuntutan pembelajaran tersebut. Hal inilah yang merangsang kemampuan berpikir kritis dan pendalaman konsep oleh peserta didik sehingga akan lebih mampu memahami materi pembelajaran yang diberikan. Uraian diatas menunjukkan bahwa rumusan masalah kedua dalam telah terjawab, yaitu ada pengaruh penerapan model pembelajaran problem posing terhadap peningkatan hasil belajar peserta didik.

\section{KESIMPULAN}

Berdasarkan analisis data yang telah dilakukan baik secara deskriptif maupun secara inferensial dapat ditarik kesimpulan bahwa hasil belajar peserta didik dengan penerapan model pembelajaran problem posing mencapai kategori sangat baik dan terdapat pengaruh penerapan model pembelajaran problem posing terhadap peningkatan hasil belajar peserta didik. 


\section{DAFTAR PUSTAKA}

[1] Departemen Pendidikan dan Kebudayaan Republik Indonesia, Peraturan Menteri Pendidikan dan Kebudayaan Republik Indonesia Nomor 70 Tahun 2013 tentang Kerangka Dasar Dan Struktur Kurikulum Sekolah Menengah Kejuruan/ Madrasah Aliyah Kejuruan. Jakarta: Departemen Pendidikan dan Kebudayaan Republik Indonesia, 2013

[2] Behizadeh, Nadia, Enacting Problem Posing Education Through Project Based Learning. English Journal, (Online), 104.2 (2014):99 - 104, 2014..

[3] Sardiman, Interaksi dan Motivasi Belajar Mengajar, Jakarta: PT. Raja Grafindo Persada, 2011.

[4] Purwanto, Ngalim, Psikologi Pendidikan, Bandung: PT. Remaja Rosdakarya, 2003.

[5] Sagala, Syaiful, Konsep dan Makna Pembelajaran. Bandung: Alfabeta, 2010

[6] Siregar, E. \& Nara, H, Teori Belajar dan Pembelajaran. Bogor: Ghalia Indonesia, 2014.

[7] Suryabrata, Sumadi, Psikologi Pendidikan. Jakarta: Rajawali Pers, 2011.

[8] Rusman, Model-Model Pembelajaran (Megembangkan Profesionalisme Guru). Jakarta: PT Raja Grafiindo Persada, 2013.

[9] Silver, E.A. \& Cai, J, An Analysis of Arithmetic Problem Posing by Middle School Student. Journal For Research in Mathematics Eduucation, (Online), 27: 293-309, 1996.

[10] Astra, I. M., Umiatin \& Jannah, M, Pengaruh Model Pembelajaran Problem Posing Tipe Pre-Solution Posing Terhadap hasil Belajar Fisika dan Karakter Siswa SMA. Jurnal Pendidikan Fisika Indonesia, (Online), ISSN: 1693-1246, 2012, (http://journal.unnes.ac.id/artikel_nju/JPFI/2153. [Diakses tanggal 2 Februari 2016].

[11] Setiawan, E. N., Prihandono, T., \& Nuriman, Pengaruh Model Problem Posing Tipe Semi Terstruktur dalam Pembelajaran Fisika Kelas XI IPA di SMA Negeri 3 Jember. Jurnal Pembelajaran Fisika, (Online), Volume1, Nomor 3. ISSN:2301-9794, 2012.

[12] Sriwenda, A., Mulyani, B. \& Yamtinah, S. 2013. Penerapan Pembelajaran Model Problem Posing untuk Meningkatkan Kreativitas dan Prestasi Belajar Siswa pada Materi Laju Reaksi Kelas XI IPA 5 SMA Negeri 1 Boyolali Tahun Pelajaran 2012/2013. Jurnal Pendidikan Kimia, (Online), Vol. 2, No 2. ISSN 2337-9995.

(http://download.portalgaruda.org/article.php?article=107495\& val=4061. Diakses tanggal 25 Januari 2016)

[13] Hafsanuddin, I., Abdurrahman \& Nyeneng, I. D. P, Pengaruh Model Pembelajaran Problem Posing Terhadap Kemampuan Berfikir Kreatif dan Hasil Belajar. Pendidikan Fisika FKIP Unila, (Online),Vol. $2, \quad$ No. 6 (http://jurnal.fkip.unila.ac.id/index.php/JPF/article/view/5938/3674 ,2014, Diakses tanggal 26 Januari 2016

[14] Mishra, S. \& Iyer S. 2015. An exploration of problem posing-based activities as an assessment tool and as an instructional strategy. Research and Practice in Technology Enchanced Learning. A Springer Open Journal, (Online), DOI 10.1007/s41039-015-0006-0. (http://www.it.iitb.ac.in/ sri/ papers/ problem Posing - rptel 2015. pdf. Diakses tanggal 28 Januari 2016)

[15] Sugiyono, Metode Penelitian Pendidikan (Pendekatan Kuantitatif, kualitatif dan R\&D. Bandung: Alfabeta, 2015.
[16] Wulandari, L., Astutik, S., \& Nuriman, Penerapan Model Problem Posing dengan Metode Tugas Terstruktur dalam Pembelajaran Fisika di SMA. Jurnal Pembelajaran Fisika. ISSN 2301-9794, 2013.

[17] Da Ponte J.P. \& Henriques A, Problem Posing Based on Investifation Activities by university students. Educ Stud Math (Online) 83:145-156, 2013. 